\title{
Simulation in Architecture: Scope of Urban Developments
}

\author{
Fauzia Rahman Mouri, M.Tawfique Rahman
}

\begin{abstract}
Simulation based architecture is the new way of understanding post design phenomena. Mostly in the urban areas, how changes take place is a matter of pondering, where simulation may come to aid. Through simulation we can predict a possible outcome of a certain solution through testing it in computer generated scenarios. The main concern of this paper is to find out through intervention of infrastructure how an urban condition may occur. In this paper a particular existing urban infrastructure has been selected to make specific changes and then setting with parameters the case has been put in to the algorithm to test the results. The results came as different scenarios with the change of inputs. For the study, the river Buriganga, beside the capital city of Bangladesh, Dhaka has been chosen and in different scenarios the outcome of a mega city has been mapped showing what a change in an existing infrastructure may bring.
\end{abstract}

Keywords- Simulation; Infrastructure; Urban Design; Computer Generated Scenarios (CGS); Processing; Post Design Phenomena;

\section{INTRODUCTION}

The world has become more urban than rural since the number of people living in urban areas (3.42 billion) has exceeded the number living in rural areas ( 3.41 billion) by the middle of 2009,[1] The urban population in 2014 accounted for $54 \%$ of the total global population, up from $34 \%$ in 1960 , and continues to grow. Though the urban population growth is concentrated in the less developed regions of the world, it is estimated that by 2017, even in less developed countries, a majority of people will be living in urban areas. The world urban population is expected to increase by $84 \%$ by 2050 , from 3.4 billion in 2009 to 6.3 billion in 2050.[2] The push and pull effect is increasing with more people arriving in urban areas every day. But with a rigid or already laid out infrastructure, which is not designed concerning the future, the cities loose efficiency and with that drains the sustainability and health issues. Designing Smart Cities rather than new cities has become a dire need or perhaps the extension of the old .

\section{A. Objectives}

This research shows the scopes of simulation based

\author{
Fauzia Rahman Mouri \\ Assistant Professor, American International University-Bangladesh \\ Dhaka, Bangladesh \\ e-mail: fauzia@aiub.edu
}

\section{M.Tawfique Rahman}

Lecturer, South East University

Dhaka, Bangladesh

e-mail: mirat147@gmail.com designs and urban strategies to create more efficient cities. Our research is mostly concerned to improve the infrastructure systems to increase the efficiency of a city, regardless where the city is in the global perspective. Such simulation based post design phenomena can be useful to predict outcomes and designs for the future.

\section{B. Methodology}

The main tool of the research is based on infrastructure urbanism. The work was done on an infrastructure that is already in existence, empowered and logically experimented by the use of computational tools for modeling and simulations. For the research purpose we selected Dhaka city, the capital of Bangladesh and a particular problem of the city at present to find solution through our method.

We ended up selecting an infrastructure that is already in there and intervening with it. After putting the possible parameters into the logic algorithm, the simulations started to show different solutions and possibilities to change the locality and the human mindset.

\section{Designing the Research Project}

This is done by the study and understanding of infrastructure of Dhaka city. The problem we chose was the pollution of the river "Buriganga" which is adjacent to the south of the city. We were thinking to introduce a certain type of infrastructure in to the already existing one, to increase the value of the river to the inhabitants and thus stopping the pollution of the river. Although, the aftermath or to achieve the desired scenario is yet to find out through more researches, the possible scenarios shows a good picture of what is possible through little change in infrastructure.

Our idea allows a spontaneous growth through bottom up self-construction integrated with top down urban rules and regulations, creating an institute of awareness, among the inhabitants of the city. This solution also increases the value of the nature as one of the final out comes. It is not, that the solution will change the present scenario overnight; rather it will be a long term process that will eventually change the mindset of the people of the city.

\section{INFRASTRUCTURE}

Infrastructure of a place or in a culture is an underline basis which is known to all as a word, but with a vague idea of the whole. Though the importance of infrastructure is certain to us, without a specific idea it becomes tough to underlay an 
efficient infrastructure in many situations. To understand the importance of infrastructure it is important to understand the definition of it, may it be from some other sources or by own definition that suits the situation the best.

\section{As it has been described in dictionaries, infrastructure is:}

"The underlying base of foundation, especially for an organization or a system. [3]

\section{Also generally defined as:}

"Infrastructure is basic physical and organizational structures needed for the operation of a society or enterprise, or the services and facilities necessary for an economy to function" [4]

Bringing all those ideas under one umbrella our first thought was to give a proper definition of "infrastructure" that is rather more universal. To understand the idea further more we have used a diagram that allows us to link the notions to each other while leaving the final interpretation free for the user or the person who is trying to define infrastructure depending on his position, regardless of the situations faced.

\section{We have defined infrastructure as such:}

"Infrastructure of a place or a certain area is a system, consisting many other inter related and inter dependent individual systems those are different in their own operation but as a whole their collective impact makes the complete system work for a particular period of time. Thus from time to time and place to place the infrastructure varies, though the basic underlying foundation of need is more or less the same."

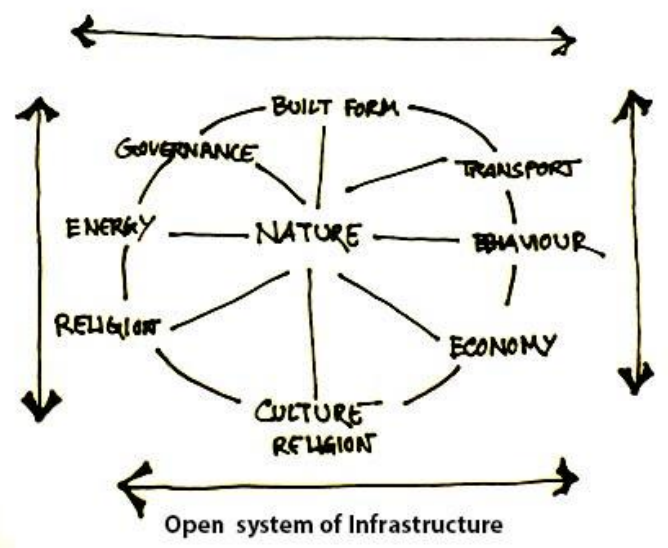

Fig. 1. Diagram Showing Infrastructure system.

The infrastructure is an open box system as shown in the figure 1, where there are scopes of further addition, subtraction or modification. The change of the system is Equidirectional. But adding another infrastructure not always results in expansion or improvement of the system. The addition and the subtraction are like a metabolic system of equation where the resultant of addition of two forms is not based on the volume or size, rather the force/ energy embedded in the forms.[5] Depending on that, the resultant may shrink or expand. In the case of infrastructure the resultant depends on the impact of the changed, added or modified system.

Also the impact of the system may vary from time to time. It is highly important to understand the role of time played in the field of infrastructure. With time not only changes occur in the physical world of service, but also the human behavioural patter or reaction to certain incidents/ services changes. Infrastructure is a changeable variable consists of more variable. Only the existence of an infrastructure is a constant but it exists in different form and intensity.

\section{Project Back Ground}

Our research project was to select a problem in the existing condition and then find out the solution while looking or searching in the existing condition itself. After that we put the findings in the computational simulation to see outcomes. Then we chose some scenarios from the result and discussed them further.

Same method was followed in "Planning for the French protectorate of Morocco", a work of Michele Ecochard, where he developed an alternative methodology to deal with the issues of rapid urbanization of these areas.[6]There is another research and design practice based in Zurich, is Urban Thinktank, whose goal is creating a new understanding of the scopes of architectural design within the real settlements. Both of the studies are an example of working with the idea of informal architecture. [7]

\section{ConTeXT}

We selected to work on the river Buriganga situation in Dhaka city, the capital of Bangladesh. The old Dhaka city, specially the riverfront of Buriganga was a landmark of the Mughal period of administration is in presently in the most chaotic condition. Originally Buckland Bund was planned to provide space for recreation. But now it has become an avenue of wholesalers, hawkers, for boats and cargo landing ground.

Since the Mughals made Dhaka their capital in 1610 the banks of the Buriganga has always been a prime location for trade. The city's main source of drinking water was also the river. But the chemical waste of mills and factories, medical waste, sewage, dead animals, home waste and oil from the vehicle has put the river in the present condition of having a severe pollution problem. Most of the city's solid waste, which is about 4,500 tons daily, is released into the Buriganga. According to the Department of the Environment (DoE), 20,000 tons of tannery waste, including some highly toxic materials, is also released into the river every day. [8]

\section{A. Dhaka city and river Buringanga}

Dhaka a city that was founded 800 years back on the very bank of the river Buriganga has always been one of the most important cities of Bangladesh. For 450 years it has been the capital of Bangladesh since the Mughal rulers declared it as one.

The area of Dhaka city is $815.8 \mathrm{sq} \mathrm{km}$, where the population is more than 15 million ensuring the density $18386.859 / \mathrm{sq} . \mathrm{km}$. More the days pass the more it is growing.[9]

The city is surrounded by three rivers from three sides. Most important among the rivers surrounding Dhaka is the river Buriganga which is on the south of the city. 


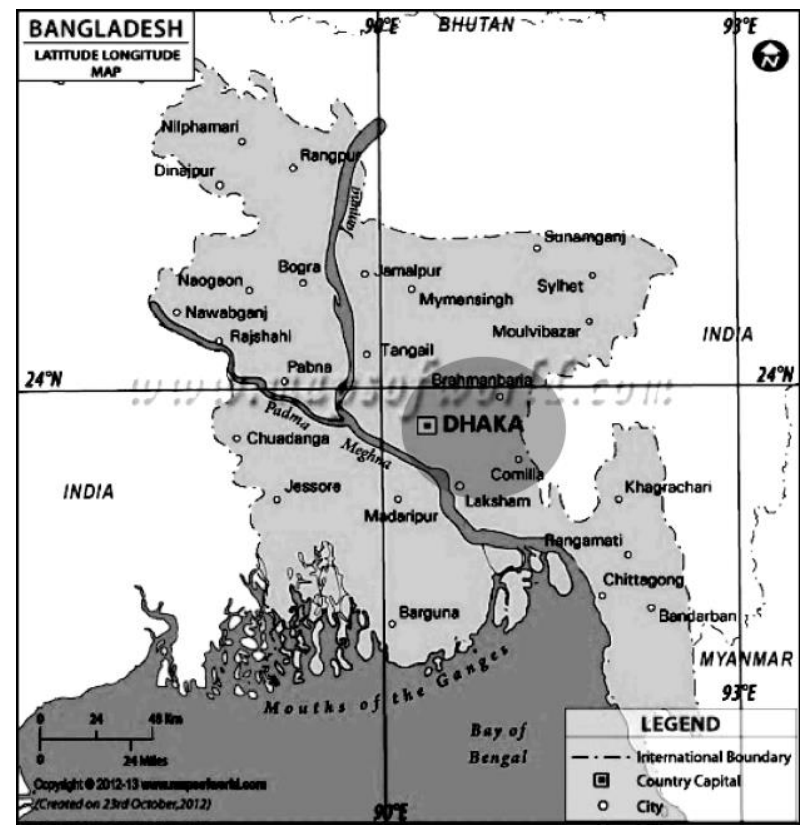

Fig. 2. Dhaka city - position.

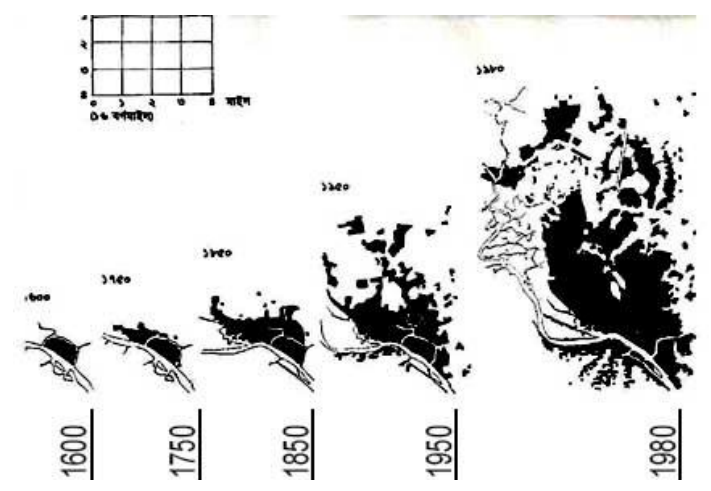

Fig. 3. Dhaka city - position and growth.

Since it's the most important the miss use of it is also at the maximum. The river has been polluted so much that it has been declared as the dead river already.. No zoological evidence is found, flora or fauna cannot live in the stretch that passes the city.[10]

"If dissolved oxygen in water lessen below 6 , it will be impossible for the aquatic animals and plants to survive. The study in January 2007 shows that at 4 among the total 9 points in Buriganga, the value of dissolved oxygen is 0 and at the rest 5 , the average value of dissolved oxygen is 1.8. The Biological Oxygen Demand (BOD) also reflects the pollution rate of water. The lower the value of the BOD in water, the lower will be the pollution rate in it. The tolerance limit of BOD in water is 2-6. But the study by BUET Civil Department in January, 2007 shows that the BOD in Buriganga at Hazaribagh area is $28[11]$
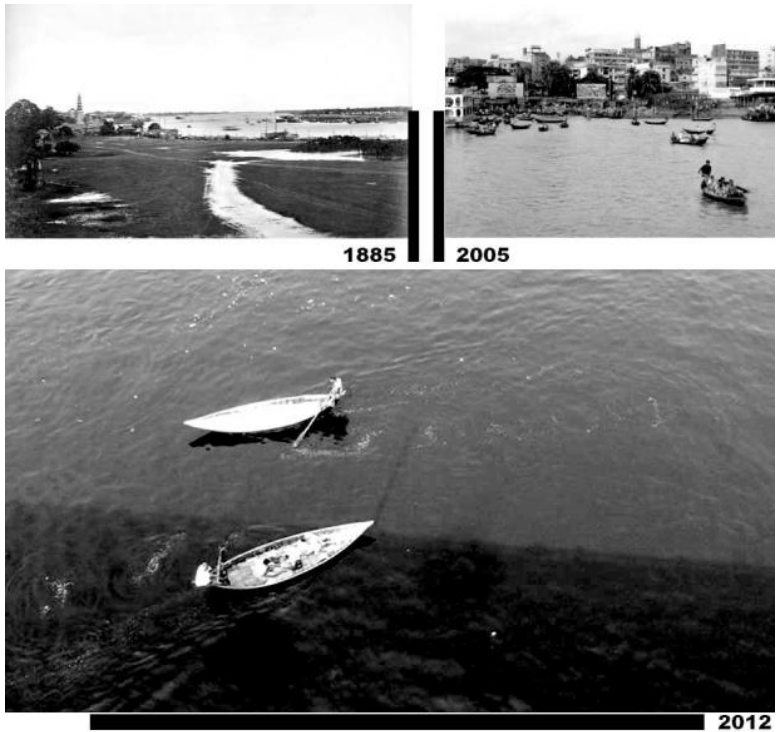

Fig. 4. River Condition with Time.1885, 2005, 2012.

We took this project mainly aiming to design architecture to guide in such a way, that the river gets cleaned and the city becomes more sustainable and healthy. To do so, we wanted our architecture to be as such that it creates an institute of awareness in people of that area, so that they keep the water clean and also stop polluting it further.

\section{RESEARCH STATEMENT}

Can a Certain change of an existing infrastructure or introduction of a new one, improve the river Buriganga condition and also create an institute of awareness to value nature more? We tried to find out a solution based on the bottom-up processes of self-construction of a city and the topdown level of urban planning. Our intention was to create an interface which is able to run simulations to predict the possible future of the design and policy solutions.

\section{Simulation in Architecture}

Beyond the design of the physical space, designers have to deal with the intangible outcomes of projects, which include allowance for the future experience of people in time and space. The purpose of design is to project the future conditions of the built environment on which we intervene. This process is called simulation which is widely used in many parts of researches. Today, the spectrum of simulation tools has dramatically increased and, most importantly, tools are becoming more and more user-friendly and widely applied. In fact, increasing interest in simulation, by society and the profession, is evident since digital representation tools are easily accessible in everyday design practice. In the last three decades, the rapid evolution of CAD and ICT (especially computer power) has enabled the complexity of design by providing greater control over the outcomes.

\section{FINDING OUT AN INFRASTRUCTURE}

It was important for us to make a set of logic algorithm in which the criteria's are divided in to differential method. Part by part the infrastructures were taken and then analyzed through those set of criteria. Some times through the literature review the infrastructures were re-thought and re arranged in a list of orders to find out links in between. Once the link was 
established it was important to find out the impact of the individual systems. And analyze their individual impact on each other and as a whole on the urban condition itself. We decided to choose an act of certain human behavior and institute of habit. And then incorporate the change in our architecture.

\section{A. Selected Infrastructure}

We found out some points, which are mostly used for entry and exit of the certain locality and those are the most randomly used points by the people to pass by. This was an important attribute of the places. We then wanted to place our architecture there which will then be able to draw attention of the maximum people in a minimum effort or time. Then we took very common urban phenomena in the city of Dhaka, and that is the existence of tea stalls, in a number of places an in large number itself. These are the little refreshment stalls for people. Which are the small form of café but mostly very informal.

\section{B. Selecting the Site/ Area}

We have selected a portion of the riverbank that is called the "sawari ghat" for the experiment and the simulations. The reason behind choosing the "sawari ghat" area was that the area itself has a rich history and it is a fish market, one of the main fish markets of the country. Figures below show the area and urban fabric of the "Sawari Ghat".

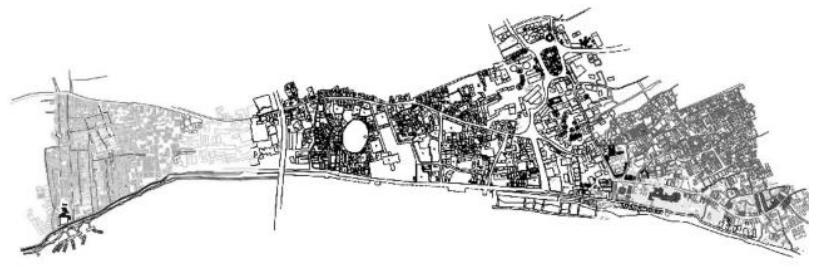

Fig. 5. Ground plan of the River Bank, south.

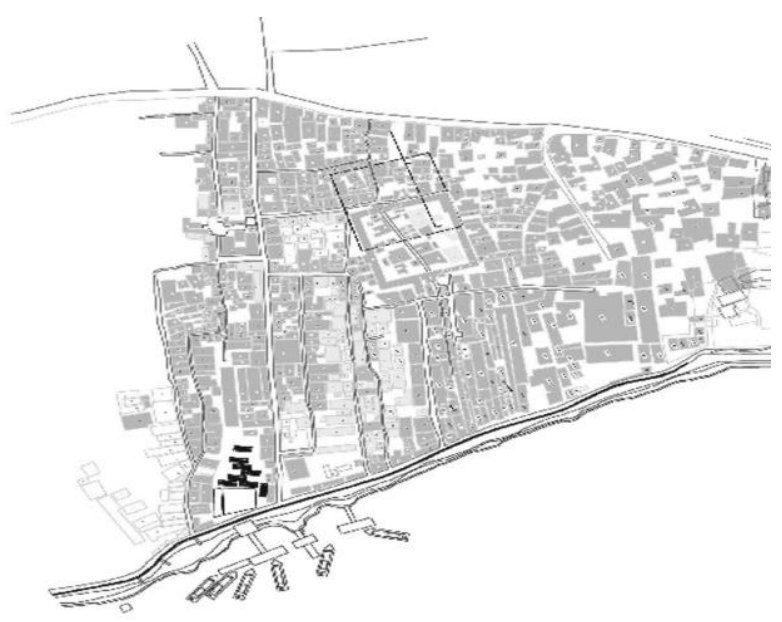

Fig. 6. Ground plan of the Selected Stretch.

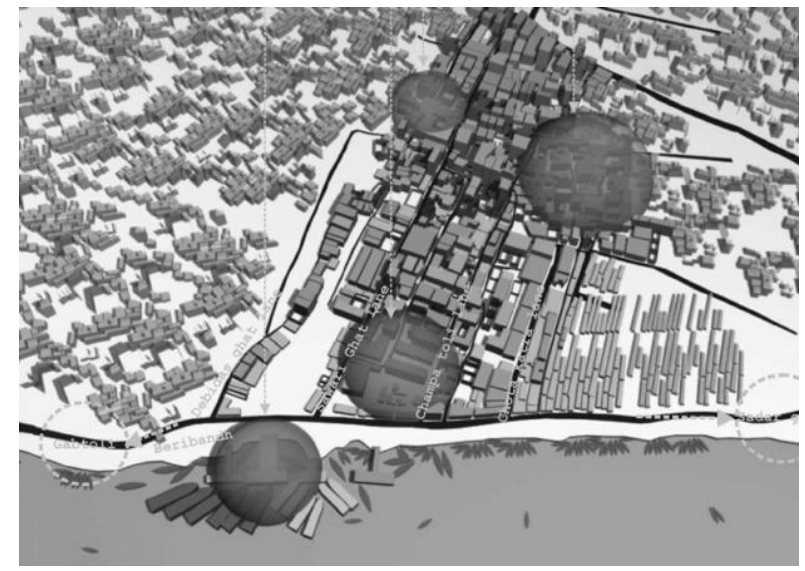

Fig. 7. Density of people at certain area.

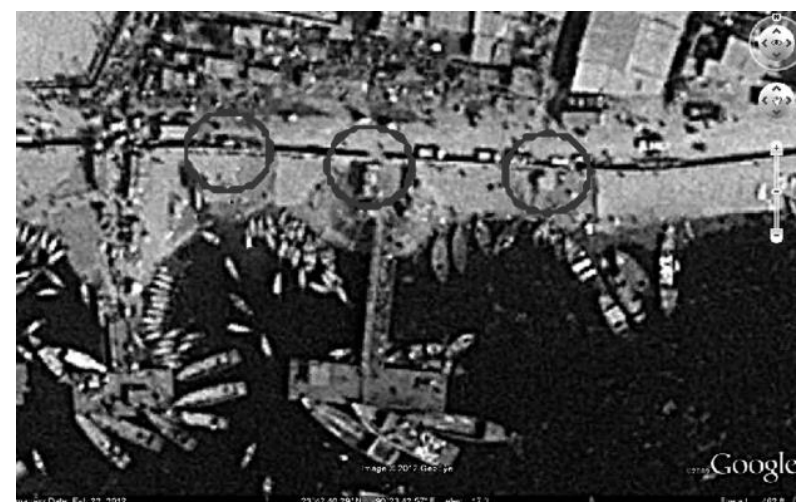

Fig. 8. Google image of the tea stalls selected points near the site.

The chunk of space we selected for our simulation is a 0.5 $\mathrm{km}$ long stretch. Figure 7 shows the position and number of the tea stalls on a chunk of place on the bank of river. These are the spots we decided to work on.

\section{Proposals}

The idea was to develop tea stalls along the river side in particular points where the boats embarks and disembarks the people who cross the river. As a result the points of entry and exits are taken into the account.

The tea stalls will be working as a waste collecting point, where people can deposit waste in exchange of some economic benefits. Since the locations are just beside a main road connected with other areas of the city, depending on how much waste they are depositing, benefits will be provided. They can either:

- Get a ticket to travel by bus

- Or to cross the river

- Or to get a cup of tea for free

- Or a snack from the stall

Since it is economically beneficial for them, first it becomes an act, a job and then ultimately a habit for the inhabitants of that area to keep it clean and therefore keeping the river clean and increasing the value of the river or nature. Also the way the tea stalls can work can give an idea to people about sustainability and idea of a green environment. 


\section{Proposed Design Module}

The design was a tea stall under a tensile structure that is anchored to the bank of the river. Material used for the tensile is jute fiber naming JUTE 13 X13 and the base is done with bamboo, where the structural members are of steel frames connected by screw and bolts.

Bamboo is used to make the internal stall furniture, but it's specially treated, called the laminated bamboo, by a process developed by BHRI-Bangladesh House and Building Research Institute. This special type of treatment increases the bamboo life span up to 10 years, protecting it from the water in the climate. Here some drawings of the structure are given:
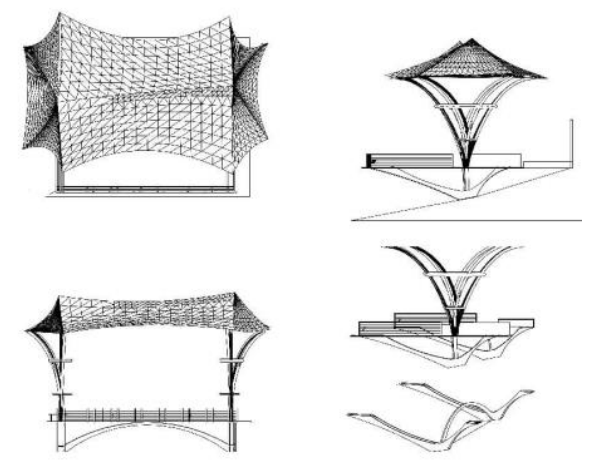

Fig. 9. View of the Designed Cell.

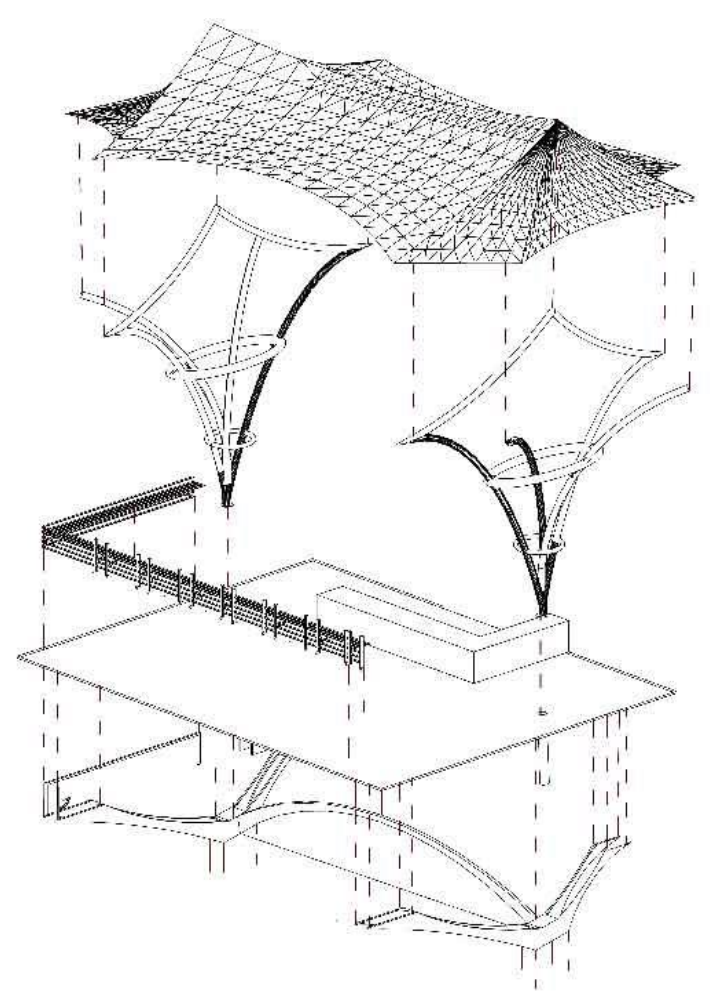

Fig. 10. Exploded view of the Designed Cell.

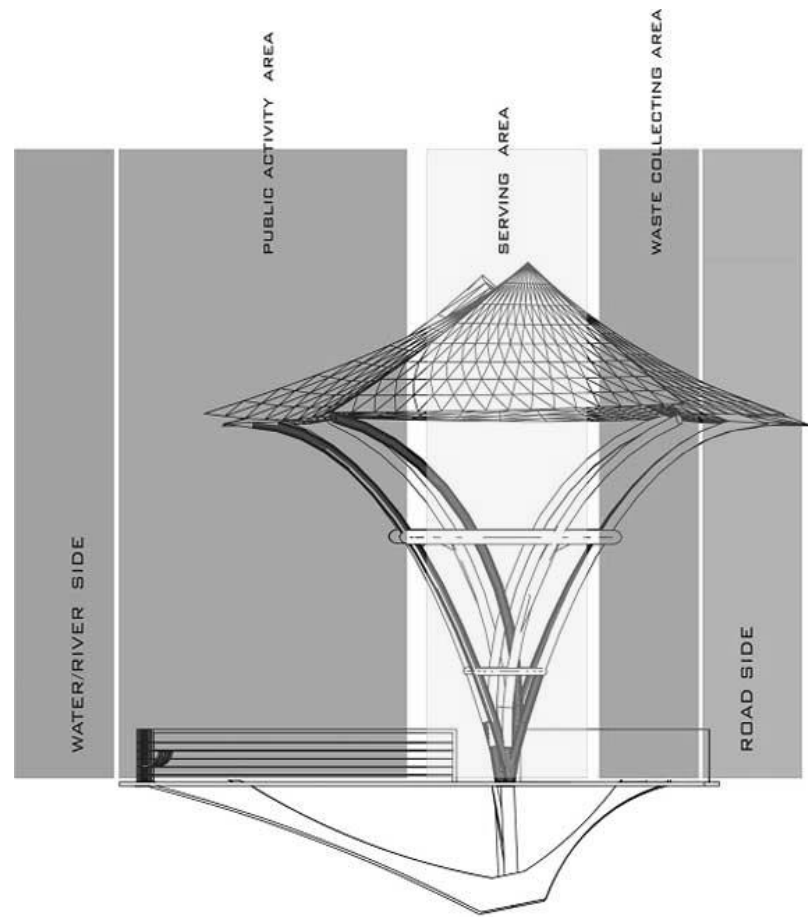

Fig. 11. Zoning of the design.

\section{Simulations}

To address the problem, this project proposes an attempt to make certain changes in an existing infrastructure and it also concerns to involve the construction and maintenances to the citizens. By breaking down the divisions between bottom-up construction and top-down planning, it opens up the possibilities to use computational tools for simulations and modeling to create scenarios by giving data of social, economic and behavioral patterns as inputs to see the possible outcomes.

One of the key processes of the design was to project the future taking the human behavior into account. As it is given into the context and circumstances, the design and the idea seems to have many out comes in future. Among the many parameters some is fixed such as the use and the possible reactions towards it, and the number of user and environmental impacts are not. Based on such parameters four of the scenarios have been chosen to present as the future projection of the possible outcome of the idea.

Specifically, this interactive planning method is constituted of series of elements:

- An urban simulation tool that will allow planners to model spatial dynamics in relation to the infrastructure at the same time it will allow the creation of certain awareness of urban processes.

- A block simulation tool that would allow for the generation and testing of a modular set of components based on self-assembly logic.

- A construction set that would allow citizens to self built their own modules and adding with the growth of the city but at the same time give the planner the possibility to embed a certain level of control and intelligence in the topology of the module itself. 


\section{A. Cellular Automata Simulation}

Cellular automata are a specific class of algorithms, constituted by a set of cells, where the change of each cell is dependent exclusively on the states of the neighboring cell. The idea has widely been researched by Michael Batty and the CASA (Center for Advanced Spatial Analysis) and expressed in the book "Cities and Complexities" [12]

By introducing multiple parameters the cell automata, that is the tea stall we are working with shows different states, allowing to track and model the transition and changing urban potentials. Thus the ultimate result is shown in the context of the river Buriganga situation improvement.

We have used the following parameters and their changes as the logic gates where the cell is the tea stall as we proposed, used as a waste collecting point or cell. Then the certain changes of the following parameters started to show interesting out comes. The parameters are:
1) Income of one cell.
2) User group.
3) Importance of the exchange of the economic benefits
4) Daily usage of the cells.
5) Daily people crossing the river
6) Daily people crossing the point by road.
7) The effect of the increased value of the waste

Nevertheless, the generic simulation appears unable to represent all the differences and specificities of the urban behavior. Yet we have chosen 4 scenarios that show the projected possible futures the best according to our notion.

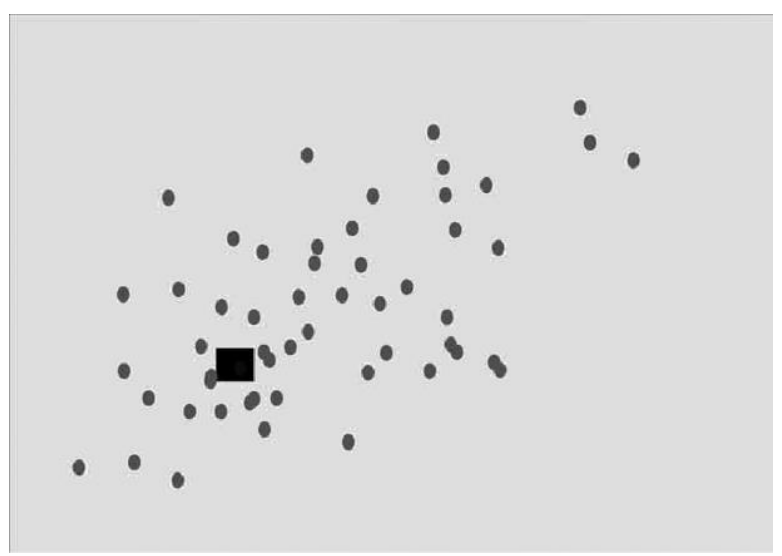

Fig. 12. Cell Simulation. t- 24 months.

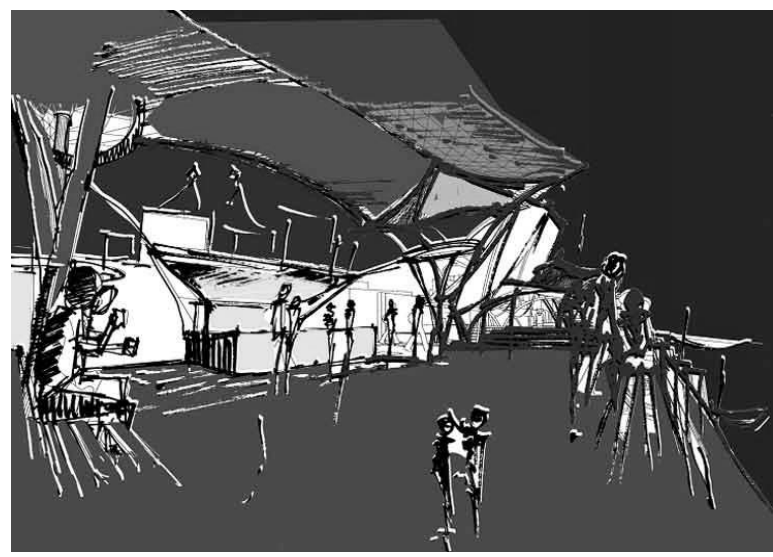

Fig. 13. Sketch Showing Scenario 1 (All Parameters in favor)

\section{B. Logic Algorithm}

We decided on the following factors as the key to change the scenarios and the inter relationship among them will guide the course of the outcome. We have decided to put a highest value and the lowest value for the parameters. Parameters are key factors of the simulations. For example we decided the highest value that can the income of one cell will reach is 10 . And the maximum of the user group may reach 10 . Then all others are set in the same category.

\section{Scenario 1}

Of the many outputs we have selected the following scene where the inputs were as follows

1) Income of one cell - Value $8 / 10$

2) User group - Value $4 / 5$

3) Importance of the exchange of the economic benefits Value 6/10

4) Daily usage of the cell-Up to 1000 persons

5) Daily people crossing the river-Up to 10000 persons

6) Daily people crossing the point by road $-\mathrm{Up}$ to 10000 persons

7) The effect of the increased value of the waste - Value $8 / 10$.

We see from the simulations that under such condition where the daily maximum 10000 people crossing the river and 10000 crossing the point, if 1000 people use the facility with economic benefit of $80 \%$, the whole project becomes a success after 2 years.

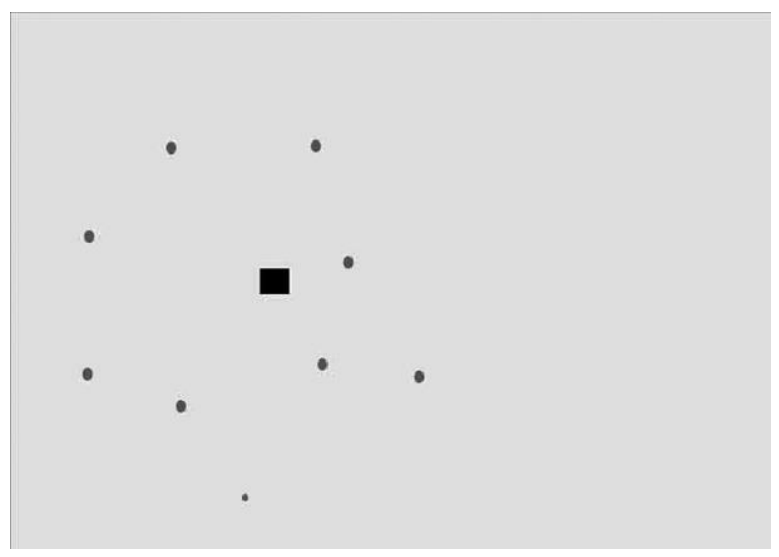

Fig. 14. Cell Simulation. t-24 months.

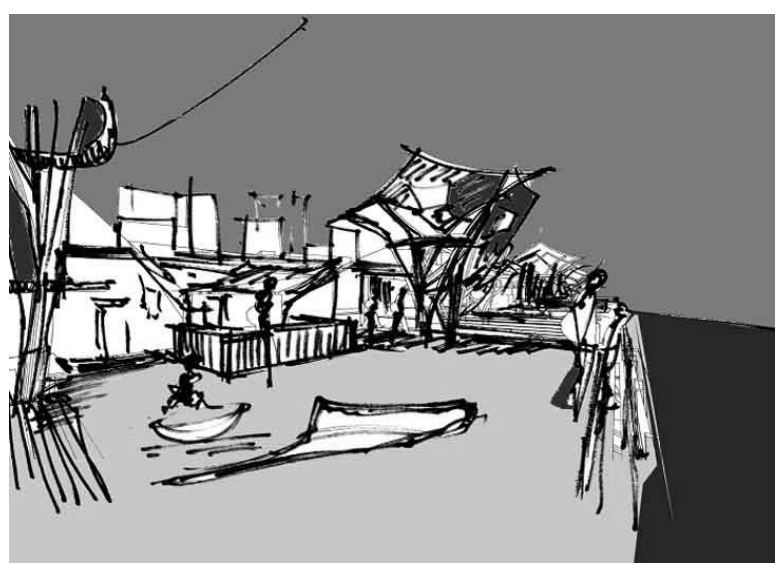

Fig. 15. Sketch Showing Scenario 2 (Parameters are Not in favor) 


\section{Conclusion for Scene 1}

The cells are working as predicted. Due to its success its maintenance is also done on a regular basis and for that it has a longer life span or re-introduced life span for the whole project. This is the primary achievement level that is expected from the idea and the design.

\section{Scenario 2}

In this scenario the user group and the income has been changed rapidly, where the predicted rumination is no longer adequate at all. The inputs were as follows.

1) Income of one cell - Value $4 / 10$

2) User group - Value $2 / 5$

3) Importance of the exchange of the economic benefits Value $6 / 10$

4) Daily usage of the cell-Up to 200 persons

5) Daily people crossing the river-Up to 10000 persons

6) Daily people crossing the point by road -Up to 10000 persons $8 / 10$

7) The effect of the increased value of the waste - Value

\section{Conclusion for Scene 2}

Due to the nature of the infrastructure of the Dhaka city even the main idea fails, the structure is used for some other purposes. The cells can become small vending areas/shops.

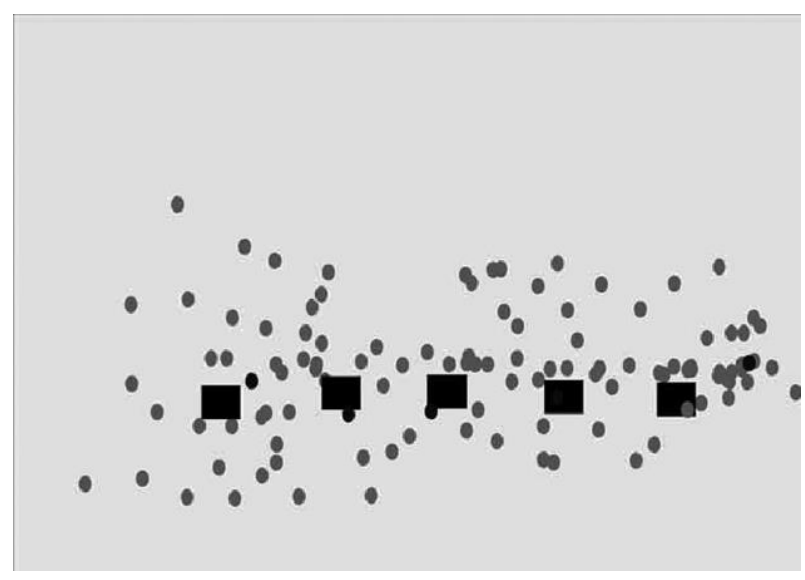

Fig. 16. Cell Simulation. t-24 months.

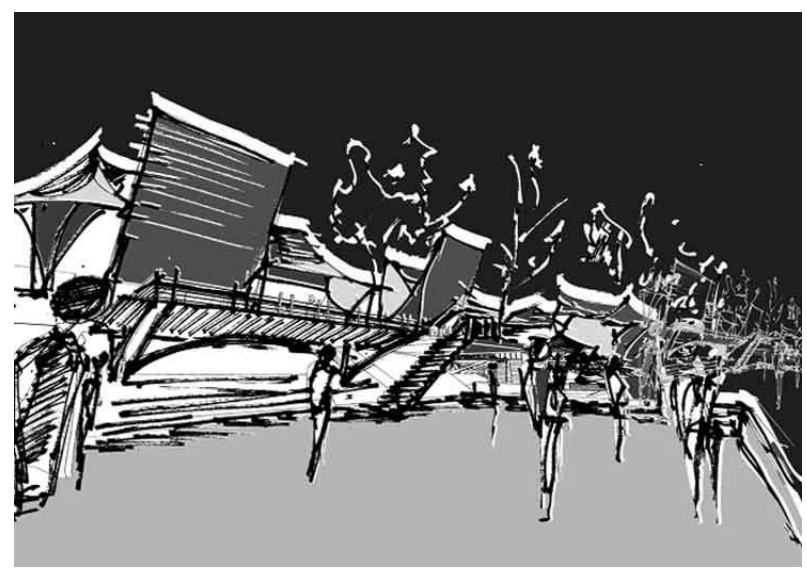

Fig. 17. Sketch Showing Scenario 3 (Parameters are in favor)

\section{E. Scenario 3}

Where the whole embankment has been developed due to the success of the architecture and new functions are introduced by the local people according to the need and investment opportunity.

1) Income of one cell - Value 10/10

2) User group - Value $4 / 5$

3) Importance of the exchange of the economic benefits Value 8/10

4) Daily usage of the cell-Up to 3000 persons

5) Daily people crossing the river-Up to 10000 persons

6) Daily people crossing the point by road -Up to 10000 persons

7) The effect of the increased value of the waste - Value $8 / 10$

\section{Conclusion for Scene 3}

It is mostly the back lash of the scene 1, where all of the units start to be successful. As this scenario takes place, the river by that time is already well improved and is a valuable asset to the people of the city as a whole.

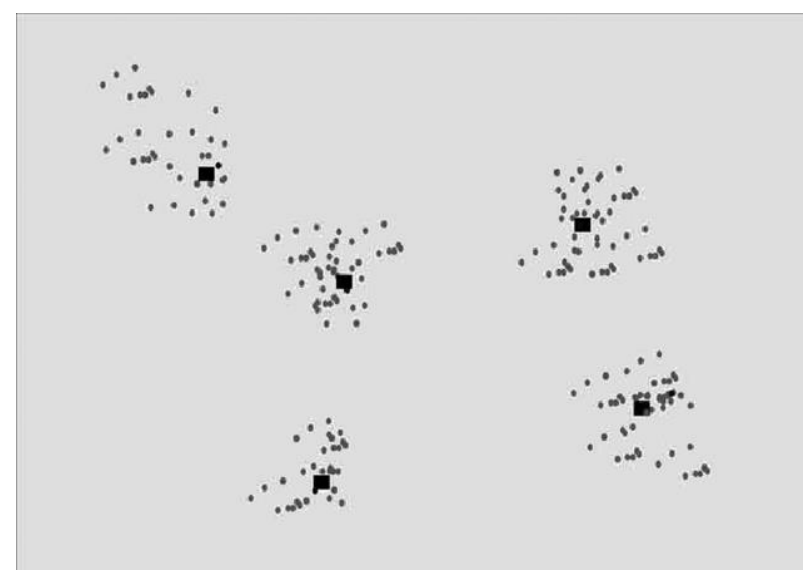

Fig. 18. Cell Simulation. t-10000.

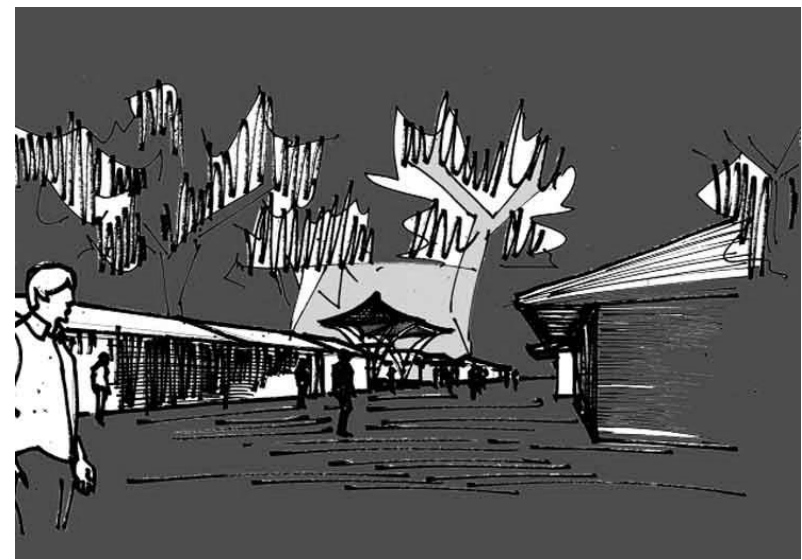

Fig. 19. Sketch Showing Scenario 4 (All Parameters are in favor) 


\section{F. Scenario 4}

Where the design and the idea has become an architectural branding and all through the country it has spread as a brand where people recognize it as a symbol generally. This scenario, the most desired one, shows where the idea has spread in to the country working as an architectural brand. The inputs were as follows:

1) Income of one cell - Value 10/10

2) User group - Value $4 / 5$

3) Importance of the exchange of the economic benefits Value $8 / 10$

4) Daily usage of the cell-Up to 7000 persons

5) Daily people crossing the river-Up to 10000 persons

6) Daily people crossing the point by road -Up to 10000 persons

7) The effect of the increased value of the waste - Value $9 / 10$

\section{Conclusion for Scene 4}

This scenario is most likely the backlash of the scene 3 , the exceeding necessity of the units/ cells can make this possible. This scenario when taken its place, doesn't only mean the better environment and quality of the river, but also, the value of nature and waste, both has changed in the course of time, therefore the mindset has become as such where the conservation is taken place not anymore as a rule, rather spontaneously through behavior. An institute of awareness has been created.

\section{Advantages}

The whole scenarios and design helps us to understand the points given below:

- THE MATERIALISTIC APPROACH OF THE DESIGN: using local material such as jute fibre and the bamboo.

- PERSONAL: where each of the people would start taking the design and the idea according to their own understanding and act as such.

- INSTITUTIONAL: the whole architecture becomes an institute of awareness to increase the value of nature to people.

The client of the project is the river Buringanga and the investors would be mostly the government and the corporate industries who want to use the units as their advertisement places.

As a whole this research paper is concerned mainly to understand the impact of certain criteria and dimensions of architecture that has been known to general people, but not quite deeply understood. Answering the question such as the materialistic side, the personal and institutional aspect and the impact as institutional aspect, changes the thinking process and also helps to understand how to start a new thinking process to begin with.

As architects we have always been defending our works as a social service, and what good it would do the society and the surrounding but barely we have judged own design from another point of view, which mostly deals with the negative impact upon the environment and the negative outcome of the establishment.

But once the exercise has been put on run, the whole new dimensions were opened and maximum efficiency has been tried to achieve through solving different problems concerning different scenarios, to minimize the impact of any change caused by the newly introduced element of infrastructure.

\section{DRAWBACKS}

It is to be understood that how to achieve the desired scenario is dependent on the situation and the existing condition and completely a variable. Depending on place and time, the output can be entirely different. To find out ways of achieving desired result is yet another research issue which has not been discussed here neither has been taken to account apart from changing selected parameters.

\section{XIII.CONCLUSION}

One of the main concerns of today's world is to have sustainable, smart and healthy cities. It is the ultimate goal of the architects and the planners to find out the design of a sound city. However, what this research tries to establish is the potential that lies in the bottom up process of urbanization while taking the existing infrastructure in to account and thus finding out the ability to construct sustainable cities within complex and hostile urban situation.

By understanding the existing infrastructure and topdown process of rule and policy making and then interlinking both can show us the different solutions to create smarter cities. At the same time finding the solutions through intertwining the changes by the newly introduced infrastructure can lead to healthier and more sustainable cities and also can solve the problems of large sectors.

When the existing infrastructure is broken down to logic gates, it is possible to construct a new paradigm for architecture and urban planning. Then the traditional rigid determinations of behaviours and acts can be substituted by the production and constitutions of awareness and institutions.

Mostly it is possible to get a sustainable, smart and healthy city by understanding the city itself as a set of dynamic infrastructures such as economic, social and environmental. Last but not least, our research shows that the proper understanding of the changes of infrastructure and the flexibility to embrace that change is a necessary condition towards achieving new smart, sustainable and healthy cities and redefining the new urban ideas.

\section{ACKNOWLEDGMENT}

We sincerely thank Prima Suriya Abdullah and Chandrabhanu Pattanayek to help us on the urban simulation tools.

\section{REFERENCES}

[1] Unattributed. (2009). World Urbanisation Prospects. Retrieved 05 19, 2016,[Online] Available at: www.unpopultaion.org: http://www.un.org/

[2] Unattributed. (2012). Global Health Observatory (GHO) data. Retrieved 09 19, 2015, [Online] Available at: /www.who.int

[3] Phyllis Ann Solari-Twadell, M. A. (2006). Parish Nursing: Development, Education, and Administration. Elsevier Health Sciences. 
[4] Owens, J. (n.d.). www.sciencedaily.com. Retrieved 6 19, 2016, [Online] Available at: https://www.sciencedaily.com/

[5] Kolarevic, B. (2000). Digital Architectures. niversity of Pennsylvania, USA (pp. 251-256). Pennsylvania: University of Pennsylvania, USA.

[6] Andrea Rox Rossi. (2013, sept 17). Issuu. Retrieved 6 2, 2016, [Online] Available at: https://issuu.com

[7] Bullivant, L. (2012). Urban Think Tank, an Interview. In L. Bullivant, Masterplanning Futures (pp. 143-145). Routledge: Routledge.

[8] Prothom alo. (2012, 5 7). Dhaka.

[9] Statistics, B. B. (2009, 9 19). BBS. Retrieved May 19, 2015, [Online] Available at: bbs.gov.bd;

[10] BHOUMIK, A. K. (2007). Buriganga Pollution: Reasons \& Prospects. Dhaka: BUET.

[11] BHOUMIK, A. K. (2007). Buriganga Pollution: Reasons \& Prospects. Dhaka: BUET.

[12] Batty,M . (2005). Cities and Complexities: Understanding Cities with Cellular Automata. In . K. Gabriel Wurzer, Agent-based Modeling and Simulation in Archaeology (p. 115). Cambridge/London: The MIT press.

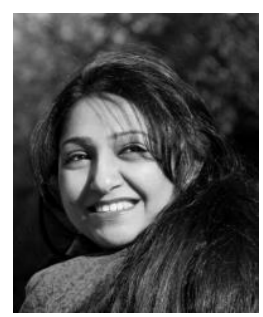

Fauzia Rahman Mouri is an Architect. Currently she is serving her job as a Assistant Professor at the Department of Architecture, AIUB after completing M.A.Arch in Architectural Design Studio on 2013, from Dessau International Architecture Graduate School, DIA under Anhalt University of Applied Science, Germany. She has done her

graduation in B.Arch from Bangladesh University of Engineering and Technology (BUET) holding the 5th position in her batch and 8th among 100. She is a faculty member in AIUB since 2014. She also worked as a Lecturer in Bangladesh
University from 2010-2011. She has a professional experience of working in an architectural firm named "Saif Ul Haque Sthapati" for one and half year. She also worked as a Masters Intern Architect at Kister Scheithauer Gross, Germany. During the study both in country and abroad she was related with extracurricular and cultural activities. This excellence in extracurricular activities started from her young age has brought her some awards and exhibitions of her own works. Her teaching interests include Architectural Design Studios, Interior Design, Graphic Arts and Architecture History.

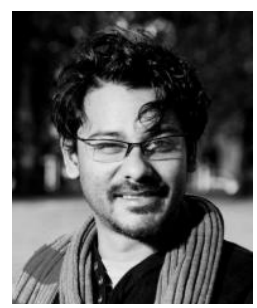

M Tawfique Rahman, is a permanent faculty member at the Department of Architecture of South East University and visiting faculty at North South University. He is working as a Lecturer since 2014. After completing his B.Arch from North South University in 2010, he did Master of Architecture in Dessau International Architecture Graduate School, DIA, under the Anhalt University of Applied

Sciences, Germany in 2013. His main interest lies in Design Theory and Urban phenomenology. Previously he has presented and published his works in conferences and journals both nationally and internationally. 
